\title{
The Optimum Amount of Road Deicing Salt in Humid Areas
}

\author{
Yu Zhang ${ }^{1}$ \\ Author ${ }^{1}$ City College Wuhan University of Science and Technology. ${ }^{1} 430083$, \\ zy19990705@126.com
}

Keywords: Wet road surface; Ice; Deicing salt; Optimum amount

\begin{abstract}
The anti-sliding performance of pavement is significant to the driving safety. In winter, frozen hazards are occurred easily in humid areas. Deicing salt is widely used to dealing with freezing for its reasonable price and remarkable effects. However, the usage of deicing salt dramatically damages environment and concrete structures. Through some tests and comparative analysis of deicing effects, the results do not rise with the increase in the amount of salt. Therefore, the optimum amount of deicing salt was proposed to minimize environment damage based on the premise of deicing.

Transportation is one of the main arteries of national economy. Road and bridge make great contribution to the development of national economy as being treated as a significant component of transport facilities. Climate of winter is frigid in most of china, especially in humid areas of Midwestern and southwestern. Thence, frozen hazards are occurred easily in winter, the anti-sliding performance of pavement will be affected, and the capacity of road will be reduced, too. Driving safety is also threatened and the probability of traffic accidents is increased. Optimal allocation for icing handle has not attracted attention in china. Negative effects still exist in current technologies. Two sides were emerged by the Usage of deicing salt and snow melting agent on road in winter. Environmental damage occurred at the same time of ice melted. Analysis and comparison were proposed depend on the experimental results of cement and asphalt concrete pavement. Thus, the optimum amount of deicing salt was proposed to minimize environment damage based on the premise of deicing.
\end{abstract}

Table 1. Margin Settings for Standard American Letter and International A4 Size

\begin{tabular}{l|c|c}
\hline Margins & Letter $(8.5$ in. $\mathbf{~ 1 1 ~ i n . ) ~}$ & $\mathbf{A 4}(\mathbf{2 1} \mathbf{c m} \times \mathbf{2 9 . 7} \mathbf{~ c m})$ \\
\hline Top & 1.00 in. & $3.50 \mathrm{~cm}$ \\
Bottom & 1.00 in. & $3.50 \mathrm{~cm}$ \\
Left & 1.375 in. & $3.25 \mathrm{~cm}$ \\
Right & 1.375 in. & $3.25 \mathrm{~cm}$ \\
\hline
\end{tabular}

\section{The Preparation of Materials and Data Measurement}

\section{Parameters of Cement concrete specimens}

Friction coefficient of cement specimens produced for the experiment — determined the BPN by Pendulum type friction coefficient measuring instrument

Table 2 Friction coefficient of cement specimens produced for experiment

\begin{tabular}{|c|c|c|c|c|c|c|c|}
\hline Number & Tem/ $/{ }^{\circ} \mathrm{C}$ & \multicolumn{5}{|c|}{ BPN } & Average Value \\
\hline 1 & 17.6 & 46 & 47 & 47 & 45 & 46 & 46.2 \\
\hline 2 & 17.6 & 39 & 40 & 39 & 39 & 41 & 39.6 \\
\hline 3 & 17.6 & 45 & 44 & 44 & 45 & 46 & 44.8 \\
\hline
\end{tabular}

The BPN of cement specimens were all in the limits of pavement friction requirement based on Highway Maintenance Technical Specifications (JTG H10-2009), and could be used for laboratory tests. 


\section{Parameters of Asphalt Concrete Specimens}

Friction coefficient of asphalt specimens produced for the experiment — determined the BPN by Pendulum type friction coefficient measuring instrument

Table 3 Friction coefficient of asphalt specimens produced for experiment

\begin{tabular}{|c|c|c|c|c|c|c|c|}
\hline Number & Tem $/{ }^{\circ} \mathrm{C}$ & \multicolumn{5}{|c|}{ BPN } & Average Value \\
\hline 1 & 17.6 & 38 & 38 & 37 & 36 & 35 & 36.8 \\
\hline 2 & 17.6 & 36 & 36 & 35 & 35 & 35 & 35.4 \\
\hline 3 & 17.6 & 38 & 37 & 36 & 35 & 35 & 36.2 \\
\hline
\end{tabular}

The BPN of asphalt specimens were all in the limits of pavement friction requirement based on Highway Maintenance Technical Specifications (JTJ 073-96), and could be used for laboratory tests.

Experiments under low temperature-40FDW/200 cascade low temperature refrigerator

Sets of low temperature refrigerator: the temperature was set as to keep the temperature of cement specimens between $-3^{\circ} \mathrm{C} \sim-7^{\circ} \mathrm{C}$ based on the ice formatted conditions.

Humidifier was placed in the refrigerator and adjusted to keep the humidity over $80 \%$ since ice formatted. Amount of water vapor used for the ice which had the thickness of $1 \mathrm{~mm} \sim 2 \mathrm{~mm}$ needed to be discounted. Source of water were simulated by mist projector. Situation of ice formation in low temperature in humid mountain area could be simulated by changing the amount of water.

With temperature of $-5^{\circ} \mathrm{C}$, measurement of cement pavement was $40 \mathrm{~cm} \times 40 \mathrm{~cm}$, results from calculation showed as blow:

\section{$\mathrm{V}=\mathrm{S} \times \mathrm{h}$}

$\mathrm{V}$ is the total amount of water, $\mathrm{S}$ is area of pavement which had ice covered, and here $0.16 \mathrm{~m} 2$ is taken. $\mathrm{H}$ is the height of ice.

Friction coefficients of specimens were tested after sprayed mist for 10minites in the low temperature refrigerator under the temperature of $-5^{\circ} \mathrm{C}$.

Table 4 Friction coefficient of cement specimens after ice formatted

\begin{tabular}{|c|c|c|c|c|c|c|c|c|c|}
\hline Number & $\begin{array}{c}\text { Tem. when ice } \\
\text { formatted } /{ }^{\circ} \mathrm{C}\end{array}$ & $\begin{array}{c}\text { Tem. of } \\
\text { testing/ }{ }^{\circ} \mathrm{C}\end{array}$ & $\begin{array}{c}\text { Amount } \\
\text { of mist }\end{array}$ & \multicolumn{4}{|c|}{ BPN tested } & $\begin{array}{c}\text { Average } \\
\text { value }\end{array}$ \\
\hline 1 & -5 & -3 & $160 \mathrm{ml}$ & 17 & 18 & 17 & 19 & 17 & 17.6 \\
\hline 2 & -5 & -3 & $160 \mathrm{ml}$ & 16 & 14 & 15 & 16 & 17 & 15.6 \\
\hline 3 & -5 & -3 & $160 \mathrm{ml}$ & 15 & 15 & 16 & 16 & 15 & 15.4 \\
\hline
\end{tabular}

Table 5 Friction coefficient of asphalt specimens after ice formatted

\begin{tabular}{|c|c|c|c|c|c|c|c|c|c|}
\hline Number & $\begin{array}{c}\text { Tem. when ice } \\
\text { formatted } /{ }^{\circ} \mathrm{C}\end{array}$ & $\begin{array}{c}\text { Tem. of } \\
\text { testing/ } /{ }^{\circ} \mathrm{C}\end{array}$ & $\begin{array}{c}\text { Amount } \\
\text { of mist }\end{array}$ & \multicolumn{4}{|c|}{ BPN tested } & $\begin{array}{c}\text { Average } \\
\text { value }\end{array}$ \\
\hline 1 & -5 & -3 & $160 \mathrm{ml}$ & 18 & 18 & 17 & 16 & 16 & 17 \\
\hline 2 & -5 & -3 & $160 \mathrm{ml}$ & 25 & 25 & 25 & 24 & 23 & 24.4 \\
\hline 3 & -5 & -3 & $160 \mathrm{ml}$ & 19 & 18 & 16 & 15 & 15 & 16.6 \\
\hline
\end{tabular}

\section{Experiment Plans}

The samples include the one of asphalt concrete and the one of cement concrete. Put the sample into the cryogenic box with the temperature between $-5^{\circ} \mathrm{C}$ and $-7^{\circ} \mathrm{C}$ when testing each time, and spray the water of same amount to form the ice layer 1 to $2 \mathrm{~mm}$ in thickness to freeze the sample once more. Carry out many experiments by controlling environment temperature and taking the amount of deicing salt as the variable, and record the ice removing effect caused by different amounts of salt and the phenomena that emerged in the process of deicing. 


\section{Relevant Experimental Data After Spread Deicing Salt}

Table 6 Concrete Pavement Deicing Experiment Data under Spreading Powder Deicing Salt with Different Quality

\begin{tabular}{|c|c|c|c|c|c|c|c|}
\hline $\begin{array}{c}\text { Quality of } \\
\text { spreading } \\
\text { powder } \\
\text { deicing salt } \\
\end{array}$ & $1.0 \mathrm{~g}$ & $1.5 \mathrm{~g}$ & $2.0 \mathrm{~g}$ & $2.5 \mathrm{~g}$ & $3.0 \mathrm{~g}$ & $3.5 \mathrm{~g}$ & $4.0 \mathrm{~g}$ \\
\hline $\begin{array}{l}\text { Time } \\
\text { required for } \\
\text { forming } \\
\text { cracks. }\end{array}$ & $10 \mathrm{~s}$ & $10 \mathrm{~s}$ & $5 \mathrm{~s}$ & $5 \mathrm{~s}$ & $5 s$ & $5 s$ & $5 s$ \\
\hline $\begin{array}{c}\text { Time } \\
\text { required for } \\
\text { cracks to } \\
\text { take up } 50 \% \\
\text { of total area. }\end{array}$ & $60 \mathrm{~s}$ & $45 \mathrm{~s}$ & $37 \mathrm{~s}$ & $30 \mathrm{~s}$ & $27 \mathrm{~s}$ & $27 \mathrm{~s}$ & $24 s$ \\
\hline $\begin{array}{c}\text { Time } \\
\text { required for } \\
\text { cracks to } \\
\text { take up } \\
100 \% \text { of the } \\
\text { area }\end{array}$ & $3 \min 30 s$ & $3 \min 10 \mathrm{~s}$ & $2 \min 55 s$ & $2 \min 45 s$ & $2 \min 43 s$ & $2 \min 10 \mathrm{~s}$ & $2 \mathrm{~min} 00 \mathrm{~s}$ \\
\hline $\begin{array}{c}\text { Ultimately } \\
\text { impacted } \\
\text { areas were } \\
\text { multiple of } \\
\text { original } \\
\text { area. }\end{array}$ & 0.8 & 1 & 1.2 & 1.4 & 1.5 & 1.5 & 1.5 \\
\hline $\begin{array}{l}\text { Friction } \\
\text { coefficient } \\
\text { in } 5 \\
\text { minutes. } \\
(\text { BPN) } \\
\end{array}$ & $\begin{array}{c}21 、 20 、 \\
19 、 18 、 \\
17\end{array}$ & $\begin{array}{c}25 、 25 、 \\
24 、 24 、 \\
22\end{array}$ & $\begin{array}{c}33 、 32 、 \\
31 、 31 、 \\
30\end{array}$ & $\begin{array}{c}38 、 37 、 \\
36 、 36 、 \\
34\end{array}$ & $\begin{array}{c}44 、 42 、 \\
41 、 40 、 \\
40\end{array}$ & $\begin{array}{c}43 、 44 、 \\
43 、 40 、 \\
40\end{array}$ & $\begin{array}{c}44 、 44 、 \\
43 、 40 、 \\
40\end{array}$ \\
\hline $\begin{array}{l}\text { Average } \\
\text { value of } \\
\text { BPN. }\end{array}$ & 19.0 & 24 & 31.4 & 36.2 & 41.4 & 42.0 & 42.2 \\
\hline $\begin{array}{c}\text { Average } \\
\text { value of } \\
\text { BPN after } \\
\text { forming ice. }\end{array}$ & 15.4 & 15.4 & 17.6 & 17.6 & 17.6 & 17.6 & 17.6 \\
\hline $\begin{array}{l}\text { If ice will } \\
\text { refreeze } \\
\text { after adding } \\
\text { water. }\end{array}$ & yes & yes & no & no & no & no & no \\
\hline \multicolumn{8}{|c|}{ Note: All spreading areas are $20 \mathrm{~cm} \times 20 \mathrm{~cm}$} \\
\hline
\end{tabular}


Table 7. Asphalt Pavement Deicing Experiment Data under Spreading Powder Deicing Salt with

\begin{tabular}{|c|c|c|c|c|c|c|c|}
\hline \multicolumn{8}{|c|}{ Different Quality } \\
\hline $\begin{array}{l}\text { Quality of } \\
\text { spreading } \\
\text { powder } \\
\text { deicing salt }\end{array}$ & $1.0 \mathrm{~g}$ & $1.5 \mathrm{~g}$ & $2.0 \mathrm{~g}$ & $2.5 \mathrm{~g}$ & $3.0 \mathrm{~g}$ & $3.5 \mathrm{~g}$ & $4.0 \mathrm{~g}$ \\
\hline $\begin{array}{l}\text { Time required } \\
\text { for forming } \\
\text { cracks. }\end{array}$ & $14 \mathrm{~s}$ & $14 \mathrm{~s}$ & $10 \mathrm{~s}$ & $10 \mathrm{~s}$ & $9 \mathrm{~s}$ & $9 s$ & $9 \mathrm{~s}$ \\
\hline $\begin{array}{l}\text { Time required } \\
\text { for cracks to } \\
\text { take up } 50 \% \\
\text { of total area. }\end{array}$ & $70 \mathrm{~s}$ & $65 \mathrm{~s}$ & $52 \mathrm{~s}$ & $48 \mathrm{~s}$ & $45 \mathrm{~s}$ & $40 \mathrm{~s}$ & $40 \mathrm{~s}$ \\
\hline $\begin{array}{l}\text { Time required } \\
\text { for cracks to } \\
\text { take up } 100 \% \\
\text { of the area }\end{array}$ & $4 \mathrm{~min}$ & $3 \min 45 s$ & $3 \min 40 s$ & $3 \min 15 s$ & $2 \mathrm{~min} 45 \mathrm{~s}$ & $2 \min 20 s$ & $2 \mathrm{~min} 04 \mathrm{~s}$ \\
\hline $\begin{array}{c}\text { Ultimately } \\
\text { impacted } \\
\text { areas were } \\
\text { multiple of the } \\
\text { original area. }\end{array}$ & 0.8 & 0.8 & 1 & 1.2 & 1.2 & 1.5 & 1.5 \\
\hline $\begin{array}{l}\text { Friction } \\
\text { coefficient in } \\
5 \text { minutes. } \\
(\mathrm{BPN})\end{array}$ & \begin{tabular}{|l|}
$28 、$ \\
$28 、$ \\
$26 、$ \\
$27 、 26$ \\
\end{tabular} & $\begin{array}{c}25 、 23 、 \\
22 、 22 、 \\
23\end{array}$ & $\begin{array}{c}30 、 29 、 \\
29 、 28 、 \\
27\end{array}$ & $\begin{array}{c}32 、 32 、 \\
31 、 30 、 \\
30\end{array}$ & $\begin{array}{c}35 、 34 、 \\
33 、 31 、 \\
31\end{array}$ & $\begin{array}{c}37 、 36 、 \\
34 、 33 、 \\
33\end{array}$ & $\begin{array}{c}37 、 37 、 \\
36 、 34 、 \\
36\end{array}$ \\
\hline $\begin{array}{c}\text { Average value } \\
\text { of BPN. }\end{array}$ & 27 & 23 & 28.6 & 31 & 32.8 & 34.6 & 36 \\
\hline $\begin{array}{l}\text { Average value } \\
\text { of BPN after } \\
\text { forming ice. }\end{array}$ & 24.4 & 16.6 & 17 & 17 & 17 & 17 & 17 \\
\hline $\begin{array}{l}\text { If ice will } \\
\text { refreeze after } \\
\text { adding water. }\end{array}$ & yes & yes & yes & no & no & no & no \\
\hline \multicolumn{8}{|c|}{ Note: All spreading areas are $20 \mathrm{~cm} \times 20 \mathrm{~cm}$} \\
\hline
\end{tabular}

\section{Relevant Data After the Application of Deicing Salt}

\section{BPN curve with different amounts of salt powder for cement and asphalt specimens}

Mathematical model was established utilize experimental data by Excel, Data curve drawn as followed: 


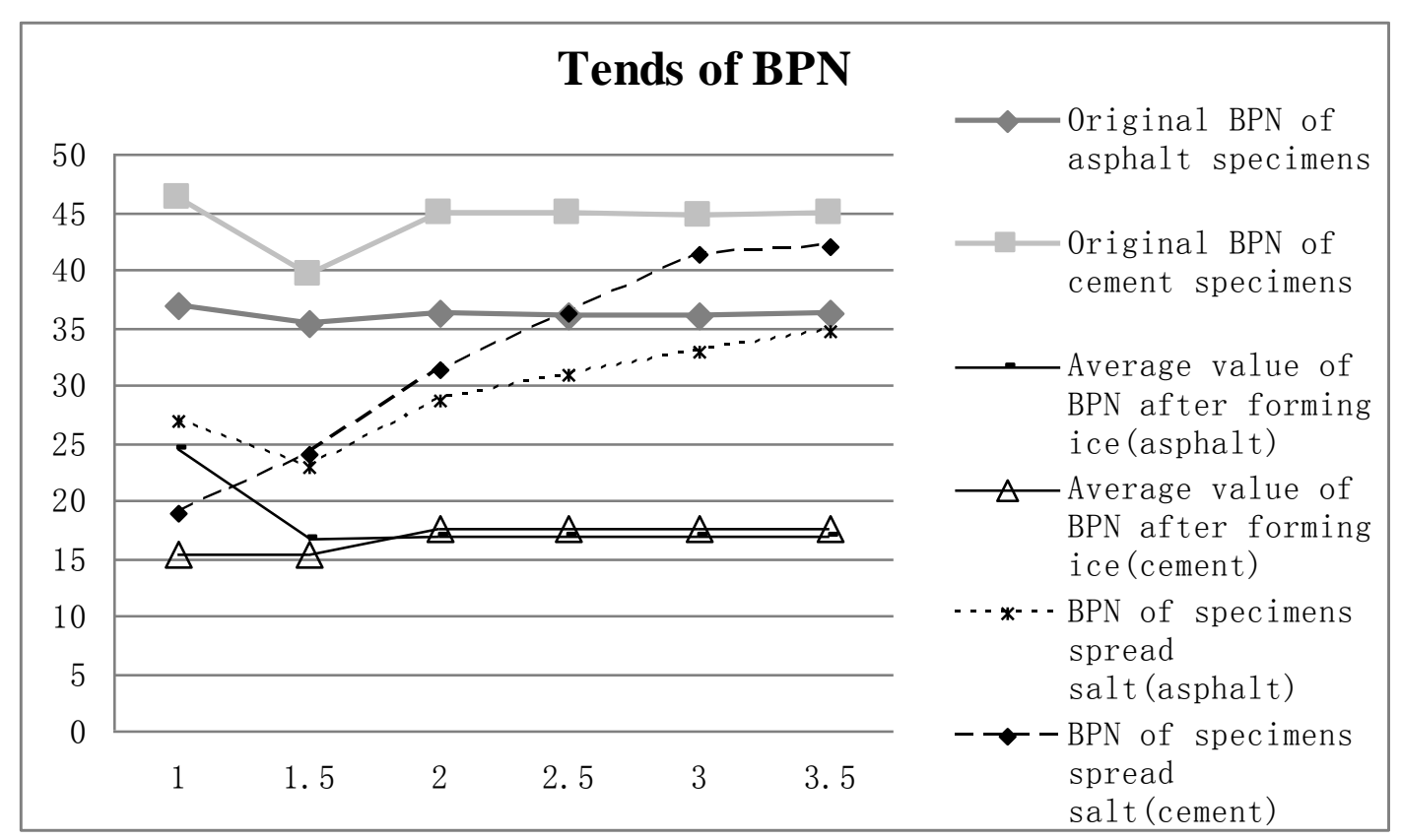

Figure 1. Contrast of BPN curve with different amounts of salt powder for cement and asphalt specimens

Results could be concluded from the curves is: if the application area is $20 \mathrm{~cm} \times 20 \mathrm{~cm}$, the deicing effect after five minutes could be measured by the BPN after the same period. With the increase of application amount of deicing salt, the deicing effect would be more notable.

The original BPN in fig1 means the BPN of specimens before iced and had not been processed. These were treated as effects references compared with BPN of specimens after deicing. The deicing effects could be represented by the disparities of BPN after iced and BPN spread salt.

As is shown in fig1, disparities of BPN of iced specimens with and without spreading deicing salt are increasing by the same time of the adding the amount of salt. Simultaneously, disparities of BPN of specimens spread salt and original BPN are decreasing. Deicing effects of asphalt and cement concrete specimens are more and more manifest.

For the sample of cement concrete, the change of BPN, after the application deicing slat between $1.0 \mathrm{~g}$ and $3.0 \mathrm{~g}$, almost increased in proportion. When the application amount is $3.0 \mathrm{~g}$, the BPN's change is slight with slow growth rate and the curve has almost become a straight line. Therefore, if application area was $20 \mathrm{~cm} \times 20 \mathrm{~cm}, 3.0 \mathrm{~g}$ salt would achieve a good effect of deicing, and more salts would not obtain much effect but damage the surrounding environment.

Similarly, the optimum application amount of deicing salt for cement asphalt pavement was $87.5 \mathrm{~g} / \mathrm{m} 2$.

Contrast of time that cracks appeared on different specimens in simulated pavement tests

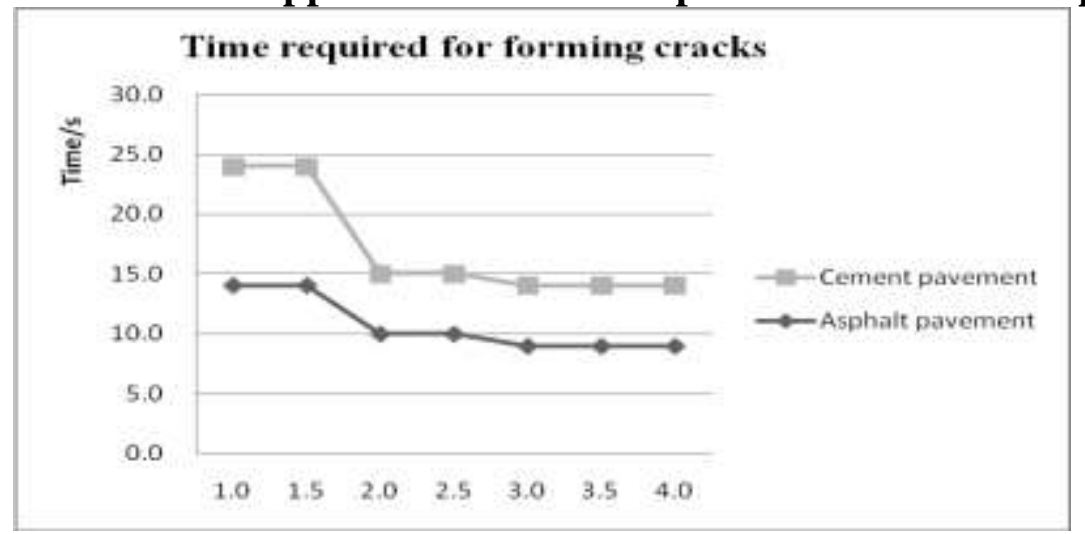

Figure 2. Contrast of time that cracks appeared on specimens which spread different amount of powder salt 
Curves in fig2 represent the time that deicing salt acted on cement and asphalt concrete specimens. The effects that different amount of deicing salt acted on same pavement structure could be compared and seen from the horizontal comparison. It is easily found that with the increasing of salt amount, the time that salt affected on pavement ice became shorter and ice melted speed up with the square of specimens was $20 \mathrm{~cm} \times 20 \mathrm{~cm}$. However, when the amount was in the range of $3 \mathrm{~g} 4 \mathrm{~g}$, the rate of change decreasing as adding more salt and time cracks appeared would remain the same. The optimum amount of deicing salt could be concluded.

Longitudinal comparisons of curves represent the effects that salt acted on asphalt and cement concrete pavement. Conclusion that time act on cement pavement is shorter than asphalt can be gotten from this.

Comparison of required for cracks to take up $50 \%$ of total area

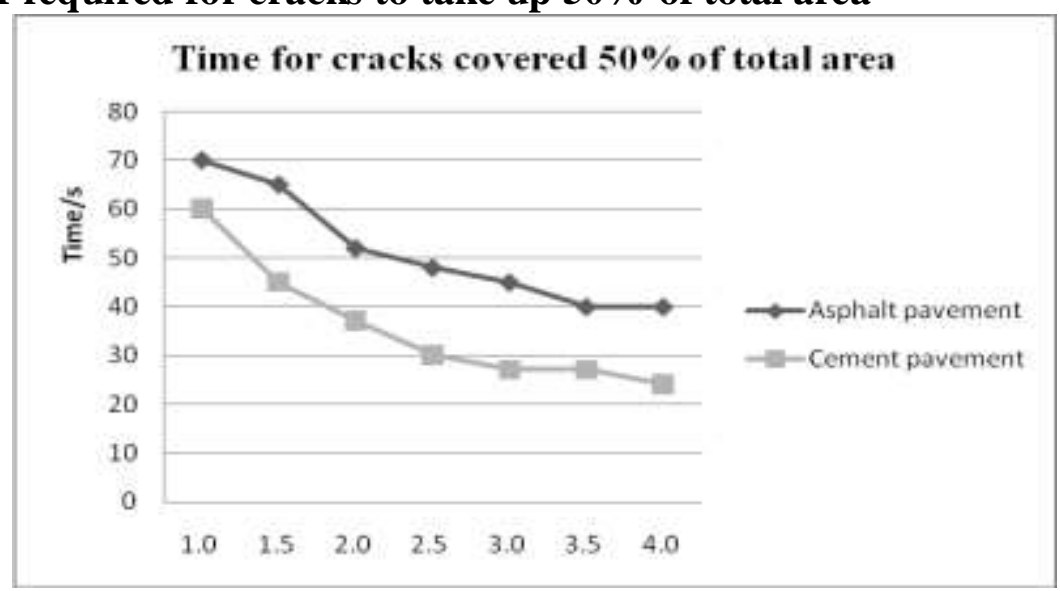

Figure 3. contrast of time that cracks covered 50\% of total area which spread different amount of powder salt

Curves in fig2 represent the time which cracks covered half of areas that deicing salt acted on cement and asphalt concrete specimens.

Contrast of time that cracks covered half of specimens which spread different amount of powder salt on the same pavement structure could be compared from the horizontal comparison. It is easily found that with the increasing of salt amount, time that cracks covered half of specimens became shorter and ice melted speed up with the square of specimens was $20 \mathrm{~cm} \times 20 \mathrm{~cm}$. And in this range, the curvature of curves is of gradient. However, when the amount was in the range of $3 \mathrm{~g} \sim \mathrm{gg}$, the rate of change decreasing as adding more salt and time cracks appeared would remain the same. The optimum amount of deicing salt could be concluded.

Longitudinal comparison of curves represents the effects that salt acted on asphalt and cement concrete pavement. This also shows that the time act on cement pavement is shorter than asphalt.

Comparison of Time required for cracks to take up $100 \%$ of the area

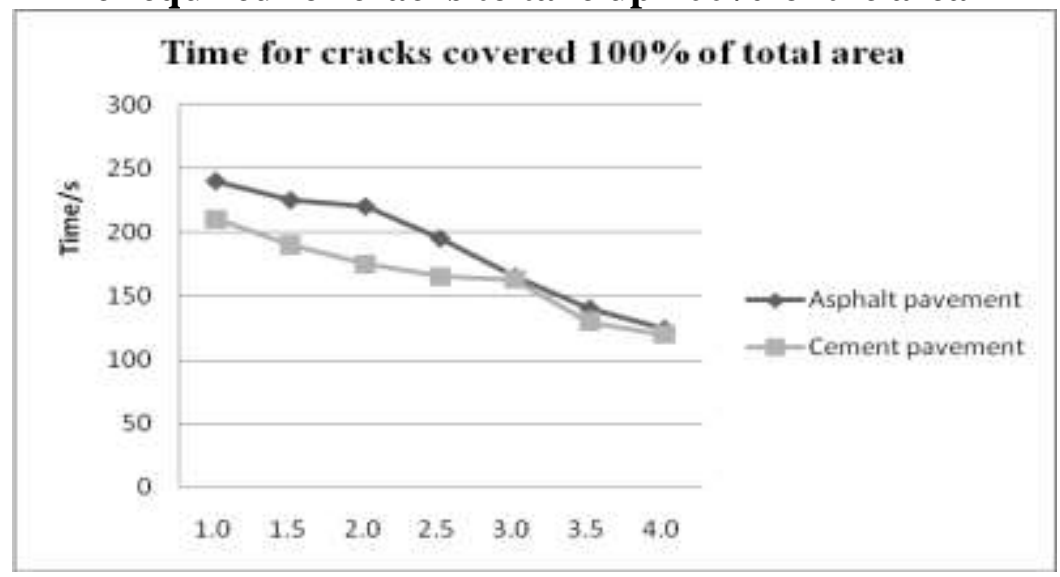

Figure 4. Contrast of time that cracks covered $100 \%$ of the area which spread different amount of powder salt 
Curves in fig2 represent the time which cracks covered all the areas that deicing salt acted on cement and asphalt concrete specimens.

Contrast of time that cracks took up the $100 \%$ of areas which spread different amount of powder salt on the same pavement structure could be compared from the horizontal comparison. It is easily found that with the increasing of salt amount, time that cracks covered all the areas became shorter and ice melted speed up when the square was $20 \mathrm{~cm} \times 20 \mathrm{~cm}$. And in this range, the curvature of curves is of gradient. However, when the amount was in the range of $3 \mathrm{~g} \sim 4 \mathrm{~g}$, the rate of change decreasing as adding more salt and time cracks appeared would remain the same. The optimum amount of deicing salt could be concluded.

Longitudinal comparison of curves represents the effects that salt acted on asphalt and cement concrete pavement. This shows that the time act on cement pavement is shorter than asphalt.

Comparison for final impact area of different specimens in simulated road test

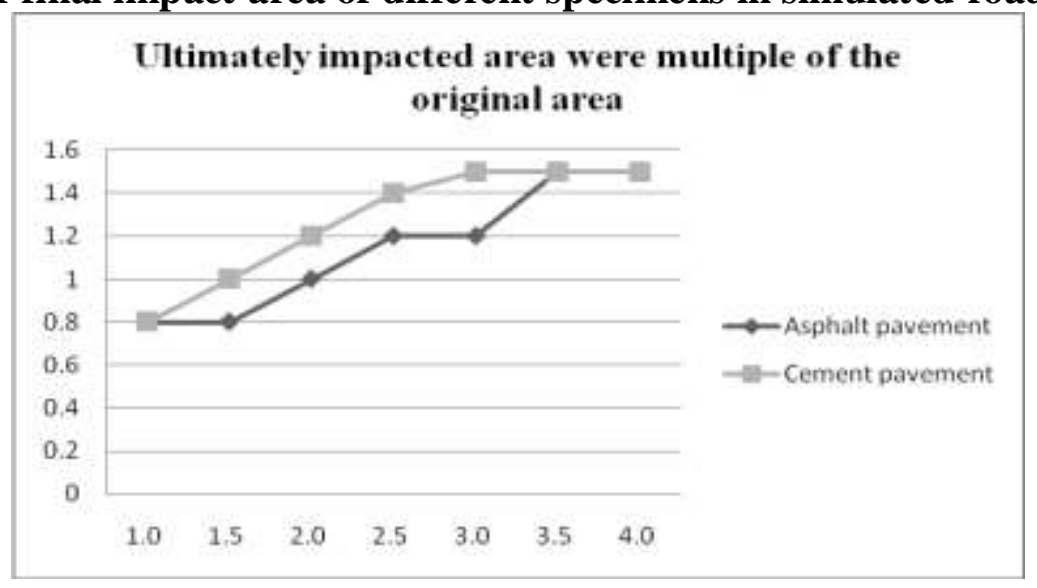

Figure 5. Comparison of final impact area of different specimens spread different amount of powder salt

The tends of ratio that Ultimately impacted areas were multiple of original area of the same pavement structure spread different amount of deicing salt could be gotten from the horizontal comparison. It is easily found that with the increasing of salt amount, the ratio decreasing with the square of $20 \mathrm{~cm} \times 20 \mathrm{~cm}$. And in this range, the curvature of curves is of gradient. However, when the amount in the range of $3 \mathrm{~g} 4 \mathrm{~g}$, the rate of change decreasing as adding more salt and time cracks appeared would remain the same. The optimum amount of deicing salt could be concluded. Relevant pictures of experiment
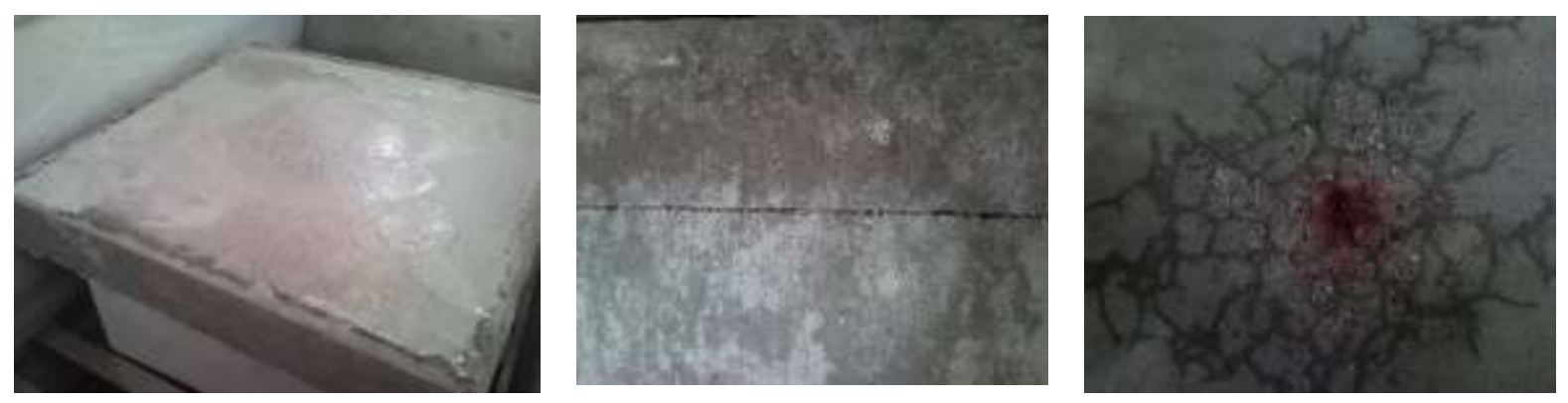

Figure6

Figure7

Figure8

Fig6 represents ice formatted on cement specimen; fig7 represents salt spread on cement specimen; fig8 represents salt acted on cement specimen.

Longitudinal comparison of curves represents the effects that salt acted on asphalt and cement concrete pavement. This also shows time act on cement pavement is shorter than asphal 


\section{Conclusions}

The best usage amount of de-icing salt which could eliminate ice more thoroughly on the cement and asphalt pavement are as followed: cement concrete pavement: $75 \mathrm{~g} / \mathrm{m}^{2}$; asphalt concrete pavement: $87.5 \mathrm{~g} / \mathrm{m}^{2}$. We can achieve the de-icing effect using less salt on the cement concrete pavement because of its smaller road constructed depth and larger stiffness. The salt usage of asphalt concrete pavement is slightly more. As long as we control the amount of deicing salt rightly when it freezes in early winter, we do not only reduce the road maintenance costs of winter and the financial pressure of the local road maintenance department, but also reduce the harm to the surrounding environment.

\section{Acknowledgement:}

This research was supported by the science foundation of National Technology Supported Program. (Project NO.:2008BAG10B01), the People's Republic of China.

\section{References}

[1] LIU Y, Yang Z, Pan T, et.al. Deicer Impacts on Pavement Materials: Introduction and Recent Developments [J].The Open Civil Engineering Journal,2009,16(27): 16-27.

[2] GAO Yan. A Method for Evaluating Uniformity of New Road Surface[J]. Hebei Jiao tong Science And Technology,2008,9(3):5-7.

[3] Cong Peiliang, Chen Shuanfa, Chen Huaxin. Effects of Deicers on Properties of Asphalt Concrete[J]. high way,2011,6(6):180-184.

[4] Dore G, Konrad J M, Roy M Role of deicing salt in pavement deterior at ions by frost action [J]. Journal Transportation Engineering, 1997, 128(4):385 -391.

[5] TAN Yiqiu, ZHAO Lidong, LAN Biwu, CHEN Kequn. Performance of Asphalt Mixture under Repeated Condensation of Ice[J].Journal of Building Materials,2011,12(6),761-766.

[6] Cody RD, Teal. Alpha methyl glucoside Project [J]. Department of Transportation Lowe, 2000, 355. 